\title{
Prenylation of Aromatic Secondary Metabolites: A New Frontier for Development of Novel Drugs
}

\author{
Alhassan M Alhassan*, Musa I Abdullahi, Ahmad Uba and Abdulrashid Umar \\ Department of Pharmaceutical and Medicinal Chemistry, Faculty of Pharmaceutical Sciences, Usmanu Danfodiyo University, \\ Sokoto, Nigeria.
}

*For correspondence: Email: alhasanma@yahoo.com; Tel: +234-8139766462

Received: 2 February 2013

Revised accepted: 4 January 2014

\begin{abstract}
Prenylation of aromatic secondary metabolites is an important process involved in the biosynthesis of many biologically active compounds in plants and animals. Many prenylated natural products have been shown to exhibit very good anti-tumor, anti inflammatory and antimicrobial activities. The addition of prenyl side chain to an aromatic secondary metabolite often affects its pharmacological activity. The aim of this review is to examine the influence of the prenyl side chain on the pharmacological activities of some classes of aromatic secondary metabolites and the potential application of prenylation in the development of novel drugs

Keywords: Secondary metabolite, Prenylation, Aromatic, Ras antagonist, Novel drugs.

Tropical Journal of Pharmaceutical Research is indexed by Science Citation Index (SciSearch), Scopus, International Pharmaceutical Abstract, Chemical Abstracts, Embase, Index Copernicus, EBSCO, African Index Medicus, JournalSeek, Journal Citation Reports/Science Edition, Directory of Open Access Journals (DOAJ), African Journal Online, Bioline International, Open-J-Gate and Pharmacy Abstracts
\end{abstract}

\section{INTRODUCTION}

Prenylation is a chemical or enzymatic addition of an isoprenoid side chain to another molecule. Prenylation of aromatic secondary metabolite is an important process involved in the biosynthesis of many biologically active compounds in plants and animals. Aromatic secondary metabolites containing prenyl side chains represent a rare class of natural products which are mainly found in plants belonging to the family of Rutaceae and to a lesser extent in the family of Apiaceae, Umbelliferae, Boraginaceae, Piperaceae, Compositae and Leguminosae [1]. A wide variety of pharmacological activities have been reported in plant secondary metabolites having prenyl residues.

The addition of a prenyl chain to an aromatic secondary metabolite often results in a derivative with improved or modified pharmacological activity. These "hybrid" natural products represent nowadays a new frontier for the development of novel drugs, in particular as antimicrobial, anti-oxidant, anti-inflammatory and anti-cancer agents [1]. The prenyl side chains are of different carbon length (Figure 1). Four types of prenyl side chain have been identified based on the size of the carbon; C5 (isopentenyl), C10 (geranyl), C15 (farnesyl) and C20 (geranylgeranyl). Compounds having the isopentenyl and the geranyl side chains are more abundant in nature while those with farnesyl and geranylgeranyl are rare. The prenyl skeleton is attached to the aromatic compound directly or through another atom such as oxygen, nitrogen or sulphur. The carbon and oxy prenylated metabolites are quite abundant while the later two are less common.

The biosynthesis of prenylated aromatic secondary metabolites involves the coupling of products from the shikimic acid and the mevalonic acid pathways. The latter produces the prenyl group while the former produces the 
aromatic compound. The two products are linked together by prenyl tranferase enzymes [2]. Many prenylated natural products have been isolated long ago, but it was only in the last decade that this class of compounds received tremendous research attention particularly, in the aspect of their pharmacological activity evaluation. Many review papers published on this subject area have focused on the isolation, classification and general pharmacology of prenylated natural products. In this review however, we have examined the influence of the prenyl group on the pharmacological activities of some classes of aromatic secondary metabolites and the potential application of prenylation in development of novel drugs.

\section{INFLUENCE OF THE PRENYL SIDE CHAIN ON THE PHARMACOLOGICAL ACTIVITY}

\section{Prenylated acridones}

Prenylated acridones are mainly found in citrus plant family of Rutaceae. They have been shown to possess various pharmacological activities, such as cytotoxity [3,4], antiviral [5] and antimalaria activities [6,7]. Itoigawa and co workers [8] evaluated 17 acridone alkaloids isolated from plants of the genera Citrus,
Glycosmis and Severinia (Rutaceae) for their anti-tumor-promoting activity in the short-term in vitro assay of Epstein-Barr virus early antigen (EBV-EA) activation. They discovered that the prenylated acridones 3-10 (Figure 2) have remarkably more potent activities compared to the non prenylated compounds with the same basic structure. Glycocitrine-II (3) and Omethylglycocirine- II (5) exhibited more potent inhibitory activity $\left(\mathrm{IC}_{50}\right.$ of 280 and $281 \mathrm{~mol}$ ratio/32 pmol TPA respectively) when compared to 1,3-Dihydroxy-10-methylacridone (1) which do not have prenyl side chain(IC ${ }_{50}$ of $368 \mathrm{~mol}$ ratio/32 pmol TPA).

Similarly the prenylated pyranoacridones (6-9) exhibited more potent antitumor promoting activity ( $\mathrm{IC}_{50} 276-302 \mathrm{~mol}$ ratio/32 pmol TPA), compared to des-N-methylnoracronycine (2) which has the same basic structure but lack the prenyl side chain $\left(\mathrm{IC}_{50} 437 \mathrm{~mol}\right.$ ratio/32 pmol TPA). Based on the results of this investigation, the group synthesized 1,3-dihydroxy-10-methyl2,4-diprenylacridone (10) a novel compound which exhibited a marked inhibitory effect on mouse skin tumor promotion in an in vivo twostage carcinogenesis test $(52 \%$ reduction in incidence of papiloma in 20 weeks). These findings<smiles>[Y]C=C(C)CCC=C(C)C</smiles><smiles>[R11]NC=[W]</smiles><smiles>CC(C)=CCCC(C)=CCCC(C)=C[14CH2]</smiles>

Figure 1: The prenyl side chains<smiles></smiles>

Figure 2: Prenylated and non-prenylated acridones 
indicate that the prenyl group is an important structural feature for good anti tumor promoting activity of the acridone molecule and can be exploited in new drug development.

\section{Prenylated coumarins}

This class of compounds is commonly found in citrus plants, family Rutaceae. They frequently occur as oxyprenylated metabolites. The oxyprenylated coumarins posses good antiinflammatory and anticancer properties. The first oxyprenylated secondary metabolite to be reported in literature is a coumarin, auraptene (11), isolated in 1930 from Citrus aurantium $L$. (rutaceae) and structurally characterized by Kariyone and Matsuno [9]. It was later discovered to be present in other plants like Zanthoxylum schinifolium [10] and Paliurus ramosissimus [11]. Auraptene was shown to be effective in preventing the chemical carcinogenesis in various rodent models including skin [12], tongue [13], liver [14], and colon carcinogenesis[15]. Another natural occurring prenyloxy coumarin is umbelliprenin (7-trans, trans-farnesyloxy coumarin) (12), isolated from Ferula persica [16]. It was shown to posses antioxidant, anti-inflammatory and lipoxygenase inhibitory activities [17]. Based on the foregoing, the effects of prenyl group on anticancer and anti-inflammatory activities of coumarins were investigated. Devji and Coworkers [18] synthesized a series of prenylated and non prenylated hydroxycoumarin derivatives and evaluated their activity against human pancreatic PANC-1 cancer cells under nutrientdeprived conditions. The results of the investigation showed that the prenylated coumarins 18 - 22 (Figure 3) exhibit higher cytotoxic activity against the PANC-1 cancer cells than 17, while 13-16 do not show any appreciable activity. The results also showed that the longer the prenyl side side chain the higher the cytotoxic activity. This study led to the discovery of a novel geranylgeranylated hydroxycoumarin (21) which exhibited $100 \%$ preferential cytotoxicity against PANC-1 cells under nutrient-deprived medium at $6.25 \mu \mathrm{M}$ making this compound a powerful new lead structure for the development of novel anticancer agents. In another related work conducted [19], O-prenylated derivatives involving farnesyloxy, geranyloxy and isopentenyloxy substituents at positions $3,4,5$, 6,7 and 8 of coumarin ring were synthesized and their lipoxygenase inhibitory activities together with the SAR studies were evaluated. The results obtained from these experiments showed that among the three groups of synthetic Oprenylated coumarins, farnesyloxy derivatives displayed the best inhibitory activity against soybean15-lipoxygenase (IC $50: 1.7$ to $5.8 \mu \mathrm{m}$ ) while the isopentenyl derivatives displayed the least $\left(\mathrm{IC}_{50}: 39.8\right.$ to $\left.69.4 \mu \mathrm{M}\right)$. The results further showed that the Lipoxygenase inhibitory potential of the coumarins is influenced by the presence and length of prenyl side chain and it decreases by 8 to 50 fold from farnesyl to isopentenyl substituents.

\section{Prenylated flavonoids}

Watjen and co-workers [20] analyzed the antioxidative potential and cytotoxic effects of two prenylflavonoids (Figure 4), licoflavone C (24) and and isobavachin (26) in comparison to their non prenylated analogues, apigenin (23), liquiritigen (25) and apigenin glucoside (27). They discovered that compounds 24 and 26 showed good cytotoxic activity against $\mathrm{C} 6$ glioma and H4IIE hepatoma cells with $\mathrm{IC}_{50}$ of $42 \pm 5$ and $96 \pm 19 \mu \mathrm{mol} / \mathrm{L}$ respectively. In contrast, compounds 23, 25 and 26 did not show any significant cytotoxic activity against the two cancer cell lines. This indicates that the insertion of prenyl group (isopentenyl) at position 8 enhances the cytotoxic activity of apigenin and liquiritigen. This property may probably be extended to other flavonoids. Further research is needed to confirm this.

\section{Prenylated chalcones}

Prenylated chalcones are commonly found in hops (cannabaceae) and few other plants. This class of compounds exhibit good antioxidant activity. The ability of some prenylated and non prenylated chalchones to inhibit the in vitro oxidation of human low density lipoprotein (LDL) was investigated by Miranda and Co workers [21]. The oxidation of LDL was assessed by the formation of conjugated dienes and thiobarbituric acid reactive substances (TBARS) and Tryptophan fluorescence. They found that the prenylated chalcones $(29,30)$ inhibited the oxidation of LDL $(50 \mu \mathrm{g}$ protein $/ \mathrm{ml})$ at concentration of 5 and $25 \mu \mathrm{m}$ while the non prenylated chalcone (28) (Figure 5) exerted prooxidant activity on LDL. This is an indication that the presence of prenyl group significantly enhances the antioxidant activity of hydroxylated chalcones.

\section{Prenylated cinnamic acids}

Artepillin C (31) and 4 geranyloxyferulic acid (34) are prenylated cinnamic acid derivatives with interesting and valuable pharmacological properties. Artepillic C (3,5-diprenyl-4hydroxycinnamic acid) was isolated from green 
Brazilian propolis which is produced from exudates of Baccharis dracunculifolia [22,23]. Artepilli $\mathrm{C}$ possesses very good anti inflammatory property [24]. Paulino and Co workers [24] investigated the anti-inflammatory effects, absorption, and bioavailability of artepillin $\mathrm{C}$ in mice. The mice were subjected to: carrageenaninduced paw oedema (300 $\mu \mathrm{g} / \mathrm{paw})$, carrageenan-induced peritonitis, and prostaglandin E2 determination. In addition, in vitro nitric oxide production by RAW 264.7 cells and NF-KB activity in HEK 293 cells were also measured. The group reported that in vivo Artepillin C produced a maximal inhibition of $38 \%$ after 360 min on paw oedema, decreased the number of neutrophils during peritonitis $\left(\mathrm{IC}_{50}: 0.9\right.$ (range 0.5 - 1.4) $\mathrm{mg} / \mathrm{kg}$ ) as well as decreased prostaglandin E2 by $29 \pm 3 \%$ and $58 \pm 5 \%$ at 1 and $10 \mathrm{mg} / \mathrm{kg}$, respectively, with a mean $\mathrm{ID}_{50}$ of 8.5<smiles>[R3]C1=Cc2ccc([R])c([R2])c2CC(=O)C1[R3]</smiles>

\section{Compound}

13

14

15

16

17<smiles>[Y]OCc1ccccc1</smiles><smiles>[Tl]OCc1ccccc1</smiles>

18

19

20<smiles>CCC(C)OC</smiles><smiles>[Tl]OC1CCCC1</smiles><smiles>COCC=C(C)C</smiles>

21<smiles>CC(C)=CCC/C(C)=C/CC/C(C)=C/CC/C(C)=C/CO[Tl]</smiles>

22

$\mathrm{H}$
R2

$\mathrm{H}$

I

$\mathrm{H}$

I

$\mathrm{H}$

$\mathrm{H}$

$\mathrm{H}$

$\mathrm{H}$

$\mathrm{H}$

$\mathrm{H}$

$\mathrm{H}$

$\mathrm{H}$

$\mathrm{H}$

$\mathrm{H}$

$\mathrm{H}$

$\mathrm{H}$

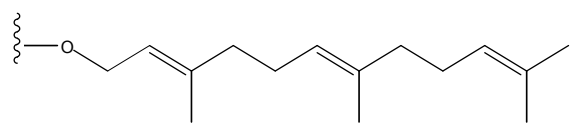

Figure 3: Structure of prenylated and non-prenylated coumarins 
<smiles>O=c1cc(-c2ccc(O)cc2)oc2cc(O)cc(O)c12</smiles>

23<smiles>CC(C)=CCc1c(O)cc(O)c2c(=O)cc(-c3ccc(O)cc3)oc12</smiles><smiles>CC(C)=CCc1c(O)ccc2c(=O)cc(-c3ccc(O)cc3)oc12</smiles><smiles>O=c1cc(-c2ccc(O)cc2)oc2c(C3OC(CO)C(O)C(O)C3O)c(O)cc(O)c12</smiles>

Figure 4: Structures of prenylated and non-prenylated flavonoids<smiles>O=C(/C=C/c1ccc(O)cc1)c1c(O)cc(O)cc1O</smiles><smiles>CC(C)=CCc1c(O)cc(O)c(C(=O)/C=C/c2ccc(O)cc2)c1O</smiles><smiles>C=CC(=O)c1c(O)cc(O)c(C/C=C(\C)CCC=C(C)C)c1O</smiles>

33<smiles>[AlH2]</smiles><smiles>O=C(O)/C=C/c1ccc(O)cc1</smiles><smiles>CC(C)=CCc1cc(/C=C/C(=O)O)cc(CC=C(C)C)c1O</smiles><smiles>COc1cc(/C=C/C(=O)O)ccc1OC/C=C(\C)CCC=C(C)C</smiles>

Figure 5: Structures of Prenylated and non prenylated chalcones (28-30) and cinnamic acids (31-34)

(range 8.0 - 8.7) mg/kg). Similarly, in in vitro models, it decreased nitric oxide production by RAW264.7 cells with a mean $\mathrm{IC}_{50}$ of 8.5 (range $7.8-9.2) \mu \mathrm{M}$. This high anti inflammatory activity displayed by this compound could probably be due to the presence of diprenyl group attached at position 3 and 5 of the molecule because the non prenylated 4-hydroxy cinnamic acid scaffold (31) (Figure 5) has been shown to possess only mild to moderate anti inflammatory activity [25]. In addition to its anti-inflammatory property, artepillin $\mathrm{C}$ has also been shown to exhibit 
remarkable antimicrobial [26] anticancer [27-29] and antioxidant activities [30,31], which may also be related to the presence of the diprenyl group. 4-Geranyloxyferulic acid (34) (Figure 5) was isolated from the bark of Acronychia baueri Schott, an Australian plant belonging to the family of Rutaceae [32]. This compound was shown to display good antitumor properties, particularly against colon related cancers [33-35]. This valuable pharmacological property has not been reported in the unprenylated ferulic acid (33) (Figure 5). This indicates that the presence of geranyloxy residue may have been partly responsible for the good anticancer property of the molecule.

\section{MECHANISM OF ACTION}

One possible mechanism by which a prenyl group may enhance or modify the pharmacological activity of aromatic secondary metabolite is through improvement of lipophilicity. The introduction of a prenyl side chain into a molecule increases its lipophilicity which could modify its pharmacological activity through enhanced access, affinity and interaction with the lipophilic membrane [36]. Another possible mechanism is the inhibition of ras signal transduction. Ras proteins constitute an important part of intracellular signal transduction system. Ras proteins are activated by attachment of farnesyl moiety. Activated RAS proteins are involved in regulating many cell functions, such as proliferation, differentiation and inflammation. RAS mutations are found in approximately one-third of human cancers, most especially in pancreatic and colorectal carcinomas [37]. Some prenylated aromatic compounds particularly, farnesyl thiosalicylic acid (35) (Figure 6) and its analogues were shown to interrupt the Ras signal cascade by interfering

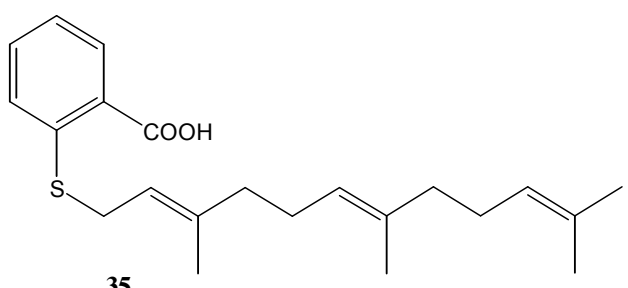

Figure 6: Structure of farnesylthiosalicylic acid

with the binding of RAS to its plasma membrane anchor protein [38-39]. Besides these two mechanisms, the prenyl moiety could exert its activity by allowing indigenous molecules to identify specific but still unknown biological targets in human and animals [40]. Further studies are, however, needed to understand the detailed mechanisms by which prenyl group influences pharmacological activity.

\section{FARNESYL THIOSALICYLIC ACID - AN EXAMPLE OF PRENYLATION IN DRUG DEVELOPMENT}

Salirasib (S-trans, trans-farnesylthiosalicylic acid, FTS, Concordia Pharmaceuticals, Ft. Lauderdale, FL) is a molecule in which the hydroxyl group of salicylic acid was replaced with a S-farnesyl group. FTS interferes with the interactions of Ras with its binding site which results in dislodgment of Ras from the cell membrane, thus preventing Ras activation and signal transduction cascade. FTS has been shown to inhibit the in vitro Ras dependent proliferation of different cancer cell lines including glioblastoma [41], pancreatic carcinomas [42], ovarian carcinomas [43] colon carcinomas [44] and prostate cancer cells [45]. FTS is currently in clinical trial. Results from the phase 1 clinical trial showed that it is effective, relatively safe and pharmacokinetics data suggest the possibility of this molecule emerging as the first available orally active Ras antagonist [46]. It is now evident that the insertion of prenyl group into an aromatic compound is a viable means through which new drugs with improved pharmacological activities could be developed. The challenge now is to extend such studies to cover wide variety of aromatic compounds including the existing drugs that are already in use.

\section{CONCLUSION}

Quite a large number of prenylated aromatic metabolites have been isolated as natural products while few were synthesized. Many studies about their pharmacological activities have been carried out in the last decade. Results from these investigations have clearly demonstrated how the presence of prenyl group improved their pharmacological activities; thus indicating the possibility of aromatic secondary metabolites as potential source of novel drugs for the treatment of diseases such as cancer, inflammation and microbial infections. The discovery of farnesyl thiosalicylic acid as Ras antagonist, further buttress the capacity of prenylation of aromatic compounds in development of new drugs. It is anticipated that future research in this area will cover a wider range of aromatic compounds besides the alkaloids and phenylpropanoids. Moreover, further studies are needed to understand the detailed mechanisms by which prenyl group influence pharmacological activity. This could 
provide a basis for rapid development of drug for the benefit of humanity.

\section{REFERENCES}

1. Epifano $F$, Genovese $S$, Menghini L, Curini $M$. Chemistry and pharmacology of oxyprenylated secondary plant metabolites. Phytochemistry 2007; 68: 939-953

2. Yazaki K, Sasaki K, Tsurumaru Y. Prenylation of aromatic compounds, a key diversification of plant secondary metabolites. Phytochemistry 2009; 70: 1739-1745

3. Bastow $K F$, Itoigawa $M$, Furukawa $H$, Kashiwada $Y$, Bori ID, Ballas LM, Lee $\mathrm{KH}$. Antiproliferative actions of 7- substituted 1,3-dihydroxyacridones; possible involvement of DNA topoisomerase II and protein kinase $C$ as biochemical targets. Bioorg Med Chem 1994; 2: 1403-1411.

4. Kawaii S, Tomono Y, Katase E, Ogawa K, Yano M, Takemura $Y$, Ju-ichi M, Ito C, Furukawa $H$. The antiproliferative effect of acridone alkaloids on several cancer cell lines. J Nat Prod 1999; 62 . 587-589.

5. Yamamoto N, Furukawa $H$, Ito $Y$, Yoshida S, Maeno K, Nishiyama, $Y$. Anti-herpesvirus activity of citrusinine-l, a new acridone alkaloid, and related compounds. Antiviral Res 1989; 12: 21-36.

6. Fujioka $H$, Nishiyama $Y$, Furukawa $H$, Kumada $N$. In vitro and in vivo activities of atalaphillinine and related acridone alkaloids against rodent malaria. Antimicrob Agents Chemother 1989; 33: 6-9.

7. Queener SF, Fujioka $H$, Nishiyama Y, Furukawa $H$, Bartlett MS, Smith JW. In vitro activities of acridone alkaloids against Pneumocystis carinii. Antimicrob Agents Chemother 1991; 35: 377-379.

8. Itoigawa M, Itoa $\mathrm{C}, \mathrm{Wu} T \mathrm{TS}$, Enjo F, Tokuda H, Nishino $H$, Furukawa $H$. Cancer chemopreventive activity of acridone alkaloids on Epstein-Barr virus activation and two-stage mouse skin carcinogenesis. Cancer Let 2003; 193: 133-138.

9. Kariyone T, Matsuno T. Studies on the constituents of orange oil.I. On the structure of auraptene. Pharm Bull 1953; 1: 19-22.

10. Jun do Y, Kim JS, Park HS, Han CR, Fang Z, Woo MH, Rhee IK, Kim YH. Apoptogenic activity of auraptene of Zanthoxylum schinifolium toward human acute leukemia Jurkat $T$ cells is associated with ER stress-mediated caspase-8 activation that stimulates mitochondria-dependent or independent caspase cascade. Carcinogenesis 2007; 28(6): 1303-1313.

11. Yu L, Zhang DM. Studies on chemical constituents from fruits of Paliurus ramosissimus. Zhongguo Zhong Yao Za Zhi 2006; 31(24): 2049-2052.

12. Murakami A, Kuki W, Takahashi Y, Yonei H, Nakamura Y, Ohto Y, Ohigashi H, Koshimizu K. Auraptene, a citrus coumarin, inhibits 12-Otetradecanoylphorbol-13-acetate-induced tumor promotion in ICR mouse skin, possibly through suppression of superoxide generation in leukocytes. Jpn J Cancer Res 1997; 88(5): 443452.

13. Tanaka T, Kawabata K, Kakumoto M, Matsunaga K, Mori H, Murakami A, Kuki W, Takahashi Y, Yonei $H$, Satoh $K$, et al. Chemoprevention of 4nitroquinoline 1-oxide-induced oral carcinogenesis by citrus auraptene in rats. Carcinogenesis 1998; 19(3): 425-431.

14. Hara A, Sakata K, Yamada $Y$, Kuno T, Kitaori N, Oyama $T$, Hirose $Y$, Murakami A, Tanaka T, Mori $H$. Suppression of beta-catenin mutation by dietary exposure of auraptene, a citrus antioxidant, in $\mathrm{N}$, $\mathrm{N}$-diethylnitrosamine-induced hepatocellular carcinomas in rats. Oncology Rep 2005; 14(2):345351.

15. Tanaka T, Kawabata K, Kakumoto M, Makita H, Hara A, Mori H, Satoh K, Hara A, Murakami A, Kuki W, et al. Citrus auraptene inhibits chemically induced colonic aberrant crypt foci in male F344 rats. Carcinogenesis 1997; 1(11): 2155-2161.

16. Iranshahi M, Shahverdi AR, Mirjani R, Amin G, Shafiee A. Umbelliprenin from Ferula persica Roots Inhibits the Red Pigment Production in Serratia marcescens. Z. Naturforsch 2004; 59(Pt C): 506508.

17. Iranshahi M, Askari M, Sahebkar A, Hadjipavlou-Litin, D. Evaluation of antioxidant, anti-inflammatory and lipoxygenase inhibitory activities of the prenylated coumarin umbelliprenin. DARU 2009; 17: (2)99103.

18. Devji T, Reddy C, Woo C, Awale S, Kadota S, CaincoMoniz D, 2011. Pancreatic anticancer activity of novel geranylgeranylated coumarine derivative. Biog Med Chem Let 2011; 21: 5770-5773.

19. Iranshahi $M$, Jabbari $A$, Orafaie $A$, Mehri $R$, Zeraatkar S, Ahmadi T, Alimardani M, Hamid S $H$. Synthesis and SAR studies of mono Oprenylated coumarins as potent 15-lipoxygenase inhibitors. Eur J Med Chem 2012; 57: 134-142

20. Watjen W, Weber N, Lou Y-j, Wang Z-q, Chovolou Y, Kampkotter A, Kahl R, Proksch P. Prenylation enhances cytotoxicity of apigenin and liquiritigenin in rat H4IIE hepatoma and C6 glioma cells. Food Chem Toxicol 2007; 45: 119-124.

21. Miranda CL, Stevens JF, Ivanov V, McCall M, Frei B, Deinzer ML, Buhler DR. Antioxidant and prooxidant actions of prenylated and nonprenylated chalcones and flavanones in vitro. J Agric F Chem 2000; 48: 3876-3884.

22. Marcucci MC, Ferreres F, Garcia-Viguera C, Bankova VS, De Castro, SL, Dantas AP, Paulino, N. Phenolic compounds from Brazilian propolis with pharmacological activities. J. Ethnopharmacol 2001; 74: 105-112.

23. Park YK, Paredes-Guzman JF, Aguiar CL, Alencar SM, Fujiwara FY. Chemical constituents in Baccharis dracunculifolia as the main botanical origin of Southeastern Brazilian propolis. I Agric Food Chem 2004; 52: 1100-1103.

24. Paulino N, Lemos Abreu SR, Uto $Y$, Koyama $D$, Nagasawa H, Hori H, Dirsch VM, Vollmar AM, Scremin A, Bretz WA. Anti-inflammatory effects of a bioavailable compound, Artepillin C, in Brazilian propolis. Eur J Pharmacol 2008; 587: 296-301.

25. Kim EOK, Min KJ, Kwon TK, Um BH, Moreau RA, Choi SW. anti-inflammatory activity of hydroxycinnamic acid derivatives extracted from corn bran in $\begin{array}{lll}\text { lipopolysaccharide-stimulated Raw } 264.7 & \end{array}$ macrophages. Food Chem Toxicol 2012; 50: 13091316.

26. Salomao K, Dantas AP, Borba CM, Campos LC, Machado DG, Aquino Neto FR, de Castro SL. Chemical composition and microbicidal activity of extracts from Brazilian and Bulgarian propolis. Lett. Applied Microbiol 2004; 38: 87-92.

27. Kimoto $T$, Koya $S$, Hino $K$, Yamamoto $Y$, Nomura $Y$, Micallef M.J, Hanaya T, Arai S, Ikeda M, Kurimoto M. Renal carcinogenesis induced by ferric nitrilotriacetate in mice, and protection from it by Brazilian propolis and artepillin C Pathol Int 2000; 50: 679-689.

28. Shimizu K, Das SK, Hashimoto $T$, Sowa $Y$, Yoshida $T$, Sakai T, Matsuura Y, Kanazawa K. Artepillin C in Brazilian propolis induces $G(0) / G(1)$ arrest via stimulation of Cip1/p21 expression in human colon cancer cells. Mol. Carcinog. 2005; 44: 293-299.

29. Orsolic N, Saranovic AB, Basic I. Direct and indirect mechanism(s) of antitumour activity of propolis and 
its polyphenolic compounds. Planta Med 2006; 72 : 20-27.

30. Hayashi K, Komura S, Isaji N, Ohishi N, Yagi K. Isolation of antioxidative compounds from Brazilian propolis: 3,4-Dihydroxy-5-prenylcinnamic acid, a novel potent antioxidant. Chem Pharm Bull 1999; 47: 1521-1524.

31. Nakanishi I, Uto Y, Ohkubo K, Miyazaki K, Yakumaru H, Urano S, Okuda H, Ueda J, Ozawa T, Fukuhara, K. et al. 2003. Efficient radical scavenging ability of artepillin C, a major component of Brazilian propolis, and the mechanism. Org Biomol Chem 2003; 1: 1452-1454.

32. Prager RH and Thregold HM. Some neutral costituents of Acronychia baueri. Aust J Chem 1996; 5: 451453

33. Curini $M$, Epifano $F$, Genovese $S$, Marcotullio MC, Menghini L. 3-(4'-Geranyloxy-3'-Methoxyphenyl )2-trans propenoic acid: a novel promising cancer chemopreventive agent. Anticancer Agents Med Chem 2006; 6: 571-577

34. Miyamoto s, Epifano F, Curini M, Genovese s, Kimi M, Ishigamori-Suzuki $R$, Yasui $Y$, Sugie $S$, Tanaka $T$. A novel prodrug of 4'-geranyloxy-ferulic acid suppresses colitis-related colon carcinogenesis in mice. Nutr Cancer 2008; 60: 675-684.

35. Tanaka T, de Azevedo MBM, Duran N, Alderete JB, Epifano $F$, Genovese $S$, Tanaka $M$, Tanaka $T$, Curini M. Colorectal cancer chemoprevention by 2 $\beta$-cyclodextrin inclusion compounds of auraptene and 4'geranyloxyferulic acid Intl J Cancer 2010; 126: $830-840$

36. Botta $B$, Vitali $A$, Menendez $P$, Misiti $D$, Delle Monache $D$. Prenylated flavonoids: pharmacology and biotechnology.Curr Med Chem 2005; 12: 717-739

37. Bos JL. Ras oncogenes in human cancer: a review. Cancer Res 1989;49(17):4682-4689

38. Haklai R, Elad-Sfadia G, Egozi Y, Kloog Y. Orally administered FTS (salirasib) inhibits human pancreatic tumor growth in nude mice. Cancer Chemother Pharmacol 2008; 61: 89-96
39. Goldberg L, Roni H, Bauer V, Heiss A, Kloog Y. New Derivatives of Farnesylthiosalicylic Acid (Salirasib) for Cancer Treatment: Farnesylthiosalicylamide Inhibits Tumor Growth in Nude Mice Models.J Med. Chem 2009; 52: (1)197-205

40. Epifano F. Chemistry and pharmacology of oxyprenylated secondary plant metabolites, [cited 2012 Dec 20]. Available from http://farmacia. unich.it/biologia/ricerca/epifano/Prenyloxysecmetab olites.pdf

41. Blum R, Jacob-Hirsch J, Amariglio N, Rechavi G, Kloog $Y$. Ras inhibition in glioblastoma down-regulates hypoxia-inducible factor-1alpha, causing glycolysis shutdown and cell death. Cancer Res 2005; 65: 999-1006.

42. Weisz B, Giehl K, Gana-Weisz M, Egozi Y, Ben-Baruch $G$, Marciano $D$, Gierschik $P$, Kloog Y. A new functional Ras antagonist inhibits human pancreatic tumor growth in nude mice. Oncogene 1999; 18: 2579-2588.

43. Beiner ME, Niv H, Haklai R, Elad-Sfadia G, Kloog Y, Ben-Baruch G. Ras antagonist inhibits growth and chemosensitizes human epithelial ovarian cancer cells. Int J Gynecol Cancer 2006; 16(1):200-206.

44. Halaschek-Wiener J, Wacheck V, Schlagbauer-Wadl H, WolV K, Kloog $Y$, Jansen $B$. A novel Ras antagonist regulates both oncogenic Ras and the tumor suppressor p53 in colon cancer cells. Mol Med 2000; 6: 693-704

45. Erlich $S$, Tal-Or $P$, Liebling R, Blum R, Karunagaran $D$, Kloog Y, Pinkas-Kramarski R. Ras inhibition results in growth arrest and death of androgen-dependent and androgen-independent prostate cancer cells. Biochem Pharmacol 2006; 72: 427-436

46. Tsimberidou AM, Rudek MA, Hong D, Chaan S Ng, Blair $J$, Goldsweig $H$, Kurzrock R. Phase 1 first-inhuman clinical study of S-trans, transfarnesylthiosalicylic acid (salirasib) in patients with solid tumors. Cancer Chemother Pharmacol 2010; 65: $235-241$ 